\title{
Inez Tuschnerová
}

\author{
Amálie Bulandrová
}

Výstava Inez Tuschnerové (1932-2015). 14. září 2018 - 27. leden 2019. Moravská galerie v Brně. Pražákův palác, Husova 18, Brno.

Kurátoři: Andrea Březinová, Ondřej Chrobák, Jiří Zahrádka

Architekt výstavy: Jitka Škopová

Grafická úprava: Lukáš Kijonka

Od září roku 2018 do února 2019 se v Moravské galerii v Brně konala retrospektivní výstava Inez Tuschnerové (1932-2015), české textilní výtvarnice, kostýmní návrhářky a akademické malířky pocházející z Brna. Coby součást výstavního projektu vydala Moravská galerie obsáhlý katalog, v němž dílo umělkyně pojednává především Andrea Březinová, spolu s Jiřím Zahrádkou a Ondřejem Chrobákem kurátorka výstavy. Texty Andrey Březinové se zabývají osobností výtvarnice, především však její textilní tvorbou a realizací v architektuře. Autorem kapitoly o abstrakci v díle Inez Tuschnerové je Petr Ingerle a část věnovanou její kostýmní tvorbě připravili Andrea Jochmanová a Jiří Zahrádka. Obsahově i formálně zdařilý rozsáhlý katalog slouží jako hlavní zdroj informací uvedených níže (TUSCHNEROVÁ, BŘEZINOVÁ a ZAHRÁDKA 2018).

Výstava se nacházela v několika místnostech přízemí Pražákova paláce, přičemž každá z nich tematizovala dílčí aspekt tvorby Tuschnerové, rozkládající se mezi oblastmi tzv. užitého umění, realizovaného především prostřednictvím netkané tapiserie, taktéž interiérového a scénického výtvarnictví, a tzv. volné tvorby zahrnující kresby, obrazy, asambláže a koláže. Historik umění
Petr Ingerle hned v úvodu svého pojednání upozorňuje, že nelze vnímat jmenované oblasti odděleně; zdůrazňuje naopak vzájemné prolínání a ovlivňování dílčích sfér, tj. jisté prostupování médií v tvorbě Tuschnerové, a připomíná také společensko-historický kontext, který její tvorbu do jisté míry určoval. ${ }^{1}$ Jmenovaná média prezentovala výstava v Pražákově paláci jak jednotlivě, prostřednictvím různých instalací, tak souborně - dílčí formy výtvarně-prostorového projevu se podařilo propojit a divákovi tak nabídnout komplexní obraz mozaiky fascinující osobnosti Inez Tuschnerové.

V přízemním atriu Pražákova paláce se návštěvník výstavy mohl nejprve seznámit s životními milníky výtvarnice, která svou uměleckou dráhu započala na konci padesátých let 20. století. Tvorba a profesní působení Tuschnerové, ostatně jako celý její život, byly těsně spojeny s městem Brno. Zde umělkyně od dětství žila, vystudovala Vyšší školu uměleckého průmyslu² - oddělení prostorového výtvarnictví, obor divadelního kostýmnictví a historie krojů u prof. Josefa A. Śálka - a později také profesně působila. ${ }^{3}$ Následovaly roky strá-

1 „[...] dílo Inez Tuschnerové vznikalo z velké části v době, kdy umělecké zakázky determinoval politický režim socialistického Československa a míra a forma spolupráce s ním určovala pohled na integritu umělce." (INGERLE 2018: 83)

2 Později přejmenovanou na Školu uměleckých řemesel.

3 Š́lek pocházel z Vídně, kde vystudoval uměleckoprůmyslovou školu u prof. Oskara Strnada a také 
vené na Vysoké škole umělecko-průmyslové v Praze, kde Tuschnerová studovala v ateliérech monumentální a užité malby prof. Aloise Fišárka (také dekorativní malby se zvláštním zaměřením na textilní umění) a divadelního kostýmu Hedviky Vlkové. ${ }^{4} \mathrm{~V}$ roce 1958 se Tuschnerové podařilo odjet do Salcburku a absolvovat letní malířský kurz Oskara Kokoschky (BŘEZINOVÁ 2018a: 7; INGERLE 2018: 90).

A právě studium u rakouského umělce je označováno za jeden ze zdrojů autorčina expresionistického gesta, rozpoznatelného v kontextu Kokoshkova požadavku na okamžité zachycení motivu, zároveň ale přesahujícího zobrazivý charakter díla: „Inez Tuschnerová si přes význam této lekce uvědomila, že expresionismus jako umělecký směr, který Kokoschka ztělesňoval, již není na pořadu dne, a že je nutné postoupit ve výtvarném vývoji dále. Od expresivního, ale stále ještě zobrazivého gesta $\mathrm{k}$ jeho postupné autonomii, až k jeho tematizaci coby vlastního sdělení“ (INGERLE 2018: 90).

Po návratu do Brna navrhovala Inez Tuschnerová kostýmy pro divadlo, zejména Národní divadlo Brno, i televizi a od roku 1967 vyučovala kostýmní historii a dějiny scénografie na Janáčkově akademii múzických umění. ${ }^{5}$ Dále navrhovala textilní ele-

divadelní seminář u teatrologa Josepha Georga. Byl architektem, scénografem a kostýmním výtvarníkem s mezinárodním rozhledem (BŘEZINOVÁ 2018a: 6).

4 Přestože nejprve nastoupila do oboru oděvnictví k prof. Hedvice Vlkové, přestoupila hned po roce na dekorativní malbu k prof. Aloisovi Fišárkovi. „Silnou pozici zde zaujímala textilní tvorba, což bylo vtěleno do celého názvu oboru: Ateliér užité a dekorativní malby se zvláštním zaměřením na textilní umění (BŘEZINOVÁ 2018a: 6).

5 „Své vzdělání doplnila v letech 1960-1963 ještě o dálkové studium estetiky na Filozofické fakultě Univerzity Karlovy. V této době už sama vyučovala v Brně na Střední průmyslové škole textilní obor Návrhářství oděvů včetně scénického kostýmu, vedle menty pro různé architektonické prostory, především jejich interiéry, a věnovala se taktéž volnému umění. Se sochařkou Sylvou Lacinovou např́klad realizovala stěnu s reliéfem a mozaikou pro výzdobu interiéru Janáčkova divadla $\mathrm{v}$ Brně, připojila se také $\mathrm{k}$ výtvarníkům ze skupiny $\mathrm{M}$ Brno (BŘEZINOVÁ 2018a: 7).

V šedesátých letech minulého století navázala výtvarnice spolupráci s Výzkumným ústavem vlnařským v Brně, kde se podílela na objevení netkané tapiserie Art Protis. Jedná se o techniku netkaných textilií, umožňující Tuschnerové realizaci netkaných nástěnných koberců, opon, dekorativních stěn a dalších unikátních textilních objektů, které byly vystavovány v mnoha evropských metropolích (BŘEZINOVÁ 2018b: 37, 46-47).

Z pozitivních ohlasů na její tvorbu v rámci prestižních mezinárodních přehlídek zahrnující především netkané tapiserie pro interiéry veřejných institucí, kostýmní návrhy pro divadlo a televizi - můžeme zmínit např́íklad výstavu v Design centru v Londýně, EXPO 1970 v Ósace, Mezinárodni bienále tapiserie v Lausanne, Bienále textilni miniatury v Szombathely, Sympozium tapiserie v Grazu (BŘEZINOVÁ 2018a: 8).

\section{Textilní (aktivní) obraz}

Textilní tvorba Inez Tuschnerové zahrnuje mnoho realizací zastoupených na pojednávané výstavě jak prostřednictvím svébytných prostorových instalací, tak dílčími skicami a návrhy. Podle dobových ohlasů byl oceňován zejména soulad návrhů Tuschnerové $\mathrm{s}$ architektonickým

toho se začala soustavně zabývat textilním uměním.“ (BǨEZINOVÁ 2018a: 7) 


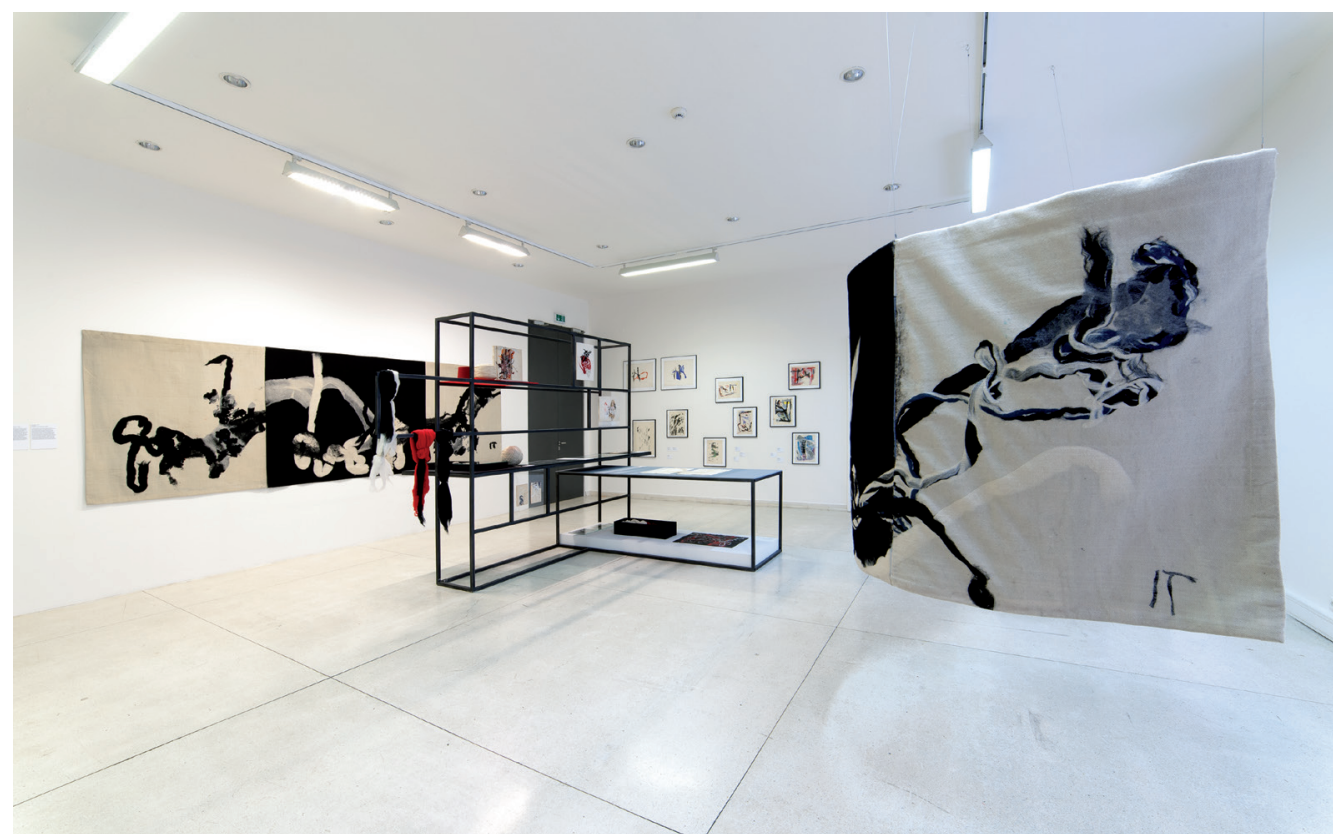

Obr. 1: Foto: Kamil Till (archiv MG)

prostorem, pro který byly textilní obrazy následně realizovány. ${ }^{6}$

Díla z počátku šedesátých let se přitom vyznačují radikální abstrakcí a inklinací k lyrickému projevu; návštěvník mohl ve výstavních prostorách nalézt objekty protknuté vertikálními gestickými motivy, propojující v některých případech malbu s koláží (kdy jsou např́klad mezi tahy štětce vlepené stříbrné kousky fólie). Jak toto tvůrčí období charakterizoval Jiří Valoch, začíná jím „autorčina cesta $\mathrm{k}$ autonomii nezobrazujícího, dynamického skripturálního gesta“ (VALOCH 2018 [2007]: 26).

Podobně, jako se ve výtvarné tvorbě pro divadlo šedesátých let setkáváme s postupným opouštěním reprezentativ-

6 Zmínit můžeme např́íklad návrh opony pro divadlo v Gottwaldově z roku 1962, který získal druhé místo, či návrh na oponu Kulturního domu v Kroměříži a mnoho dalších (BŘEZINOVÁ 2018b: 26). ního aspektu a s čím dál častější inklinací k tzv. akční scénografii ${ }^{7}$, hovoří autorka výstavy - kunsthistorička Andrea Březinové o tzv. aktivní tapiserii šedesátých let. Připomeňme, že v prvním případě jde mj. o jisté popírání výtvarnosti: „[...] každý výraznější výtvarný projev byl podezírán z dekorativnosti. Obraz prostředí, který až do šedesátých let vstupoval do procesu umělecké stylizace jako celek, se v programu akční scénografie rozkládá na významové detaily“ (PTÁČKOVÁ a DVOŘÁK 2008: 241). Aktivním spolutvơrcem akční scénografie je herec a jeho reakce-interakce, neexistující

7 "[...] od pevného textu se obrátilo k improvizaci, od dramatické stavby ke koláži, k autostylizaci, k vyhroceným osobním stanoviskům, od herectví citátu k herectví výroku. Od velkoryse koncipovaného jevištního prostoru k detailu. Rezultátem této slohové i životní proměny kritérií a současně i znakem zlatých šedesátých let se stal nový scénografický sloh, akční scénografe." (PTÁČKOVÁ a DVOŘÁK 2008: 240-241) 


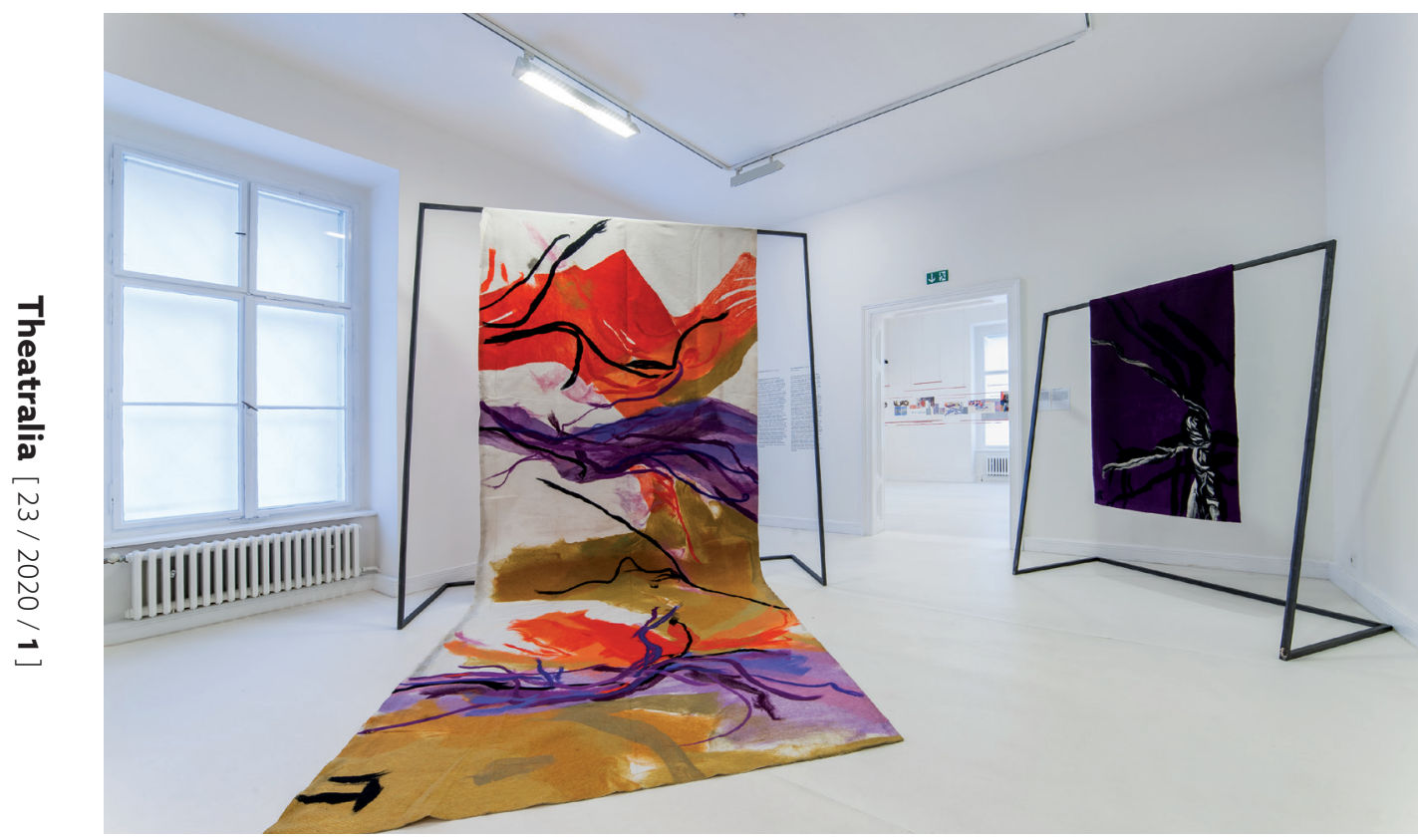

Obr. 2: Foto: Kamil Till (archiv MG)

$\mathrm{v}$ předem připraveném prostředí - to se naopak teprve spoluvytváří a aktivně proměňuje (PTÁČKOVÁ a DVOŘÁK 2008: 241).

Obdobně se i v textilní tvorbě šedesátých let hledají nové přístupy ke tkaní. Mezi hlavní témata dobových diskusí o moderní tapisérii patří podle kurátorky výstavy zejména: aktivní účast autora při realizaci díla, používání nových materiálů a hledání funkce textilie v prostoru (BŘEZINOVÁ 2018b: 26). Nové zacházení s látkou sledujeme i v záměrném ponechání nezašité části textilního celku, a to za účelem zdůraznění maximálního materiálního výrazu díla, vysvětluje v katalogu Březinová a dodává, že: „Důležitou metou se stala autorsky tkaná tapiserie oproštěná od kartonové předlohy, umělci ke tkaní přistupovali jako ,action painter" před své plátno“ (BŘEZINOVÁ 2018b: 27).

$\mathrm{V}$ kontextu tvorby Inez Tuschnerové je jediným dochovaným dílem svědčícím o hledání nového př́stupu k práci s textilií tapiserie Strom života z roku 1974 (Obr. 3), původně určená pro interiér Domu družby v Olomouci, v níž Tuschnerová „,[...] odmítá popisnost, používá př́rodní autentický materiál, klade důraz na působení struktur pro výsledný dojem díla, používá nepravidelný formát inspirovaný organickou přírodou, je závislá na (své) malî́rské předloze“ (BŘEZINOVÁ 2018b: 36).

\section{Art Protis}

Díky rozsáhlému pojednání o tuzemské textilní tvorbě druhé poloviny 20. století se z katalogu k výstavě dozvídáme, že se začátkem šedesátých let zaměstnanci Ústavu netkaných textilií soustředili na „vyvinutí zcela nového způsobu výroby oděvní textilie proplétáním nebo prošíváním rouna 


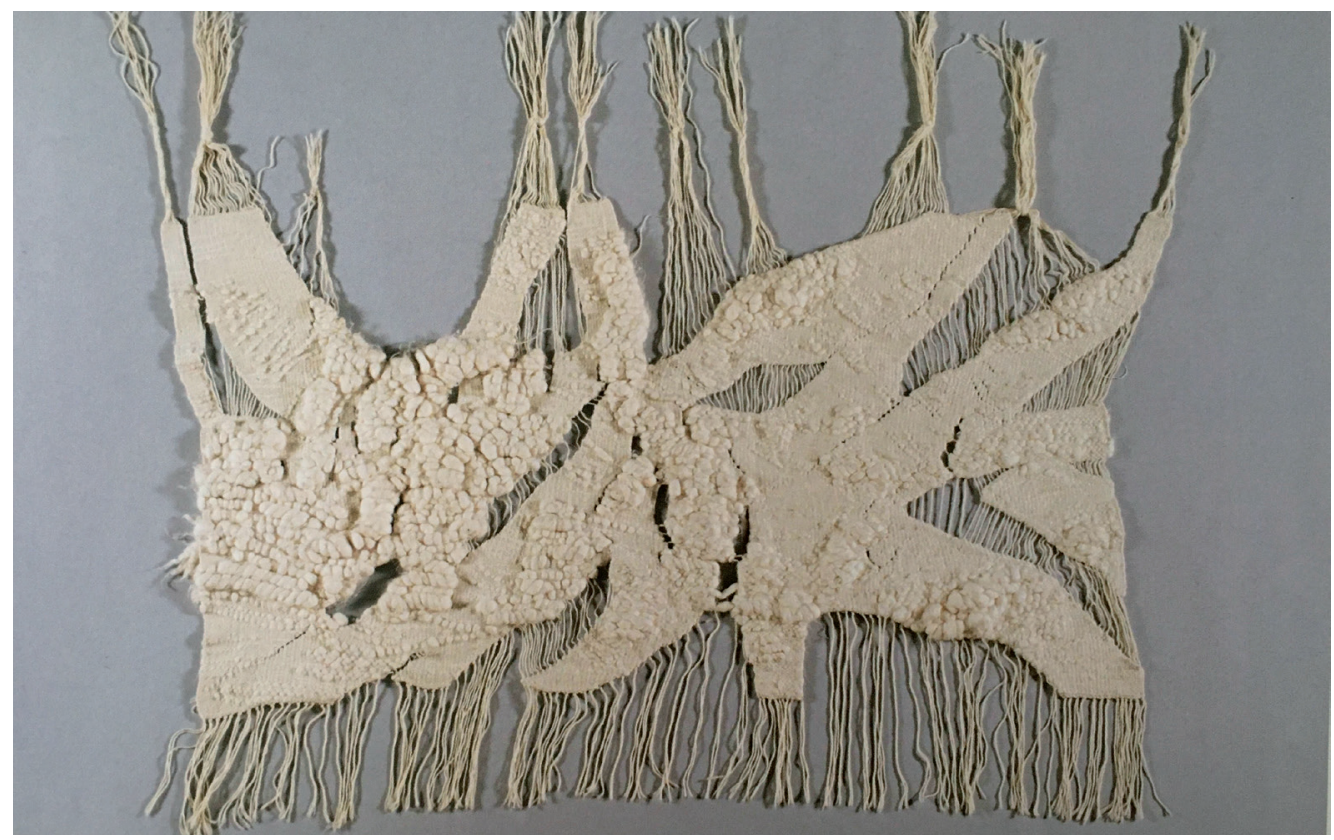

Obr. 3: Strom života, 1974

Foto: Kamil Till (archiv MG, reprodukce z katalogu, str. 32)

spolu s řídkou povrchovou tkaninou. [...] $\mathrm{V}$ dalších letech se v tomto interním úkolu pokračovalo pod názvem Protis II. Pletený předdíl, tj. lícní díl, nahradil původní předdíl tkaný, čímž se rozšířily možnosti a typy vzorování pro svrchní oděvy, uvažovat se ale začíná také o bytových tkaninách“ (BŘEZINOVÁ 2018b: 37).

Jak vysvětluje Andrea Březinová, vzniklo v roce 1965 ve VÚV samostatné oddělení Art Protis, jehož cílem bylo nabídnout novou technologii např́klad coby dekorační závěsy, textilie pro technické i oděvní účely nebo v podobě netkaných tapiserií. O pozitivním ohlasu na textilní novinku v Československu i v zahraničí přitom svědčí například zlatá medaile z Mezinárodního veletrhu řemesel v Mnichově z roku 1966 nebo prezentace této techniky coby textilních stěn Loveckého salonku Zámecké restaurace Českoslo- venského pavilonu na EXPO v Montrealu (BŘEZINOVÁ 2018b: 46).

Úspěch nového typu netkané tapiserie vysvětluje Březinová mj. tím, že se na jeho vývoji podíleli nejen textilní inženýři, ale i výtvarní umělci, mezi nimi právě Inez Tuschnerová. V době svého vzniku byla technologie považována $\mathrm{v}$ podstatě za levnější typ tapiserie - formát vhodný pro dekoraci zasedacích síní veřejných institucí a kanceláří ředitelů a náměstků (BŘEZINOVÁ 2018b: 46).

Výstava v Pražákově paláci prezentovala Art Protisy vytvořené Tuschnerovou coby samostatné cykly, naprríklad s tématem přírody či hudby, či prostřednictvím monumentálních děl, vznikajících nezřídka ve spolupráci s architektem. První z uvedených zahrnuje artefakty znázorňující živelnost přírodních jevů, jaké najdeme např́klad v cyklech Stromy či Motýli. Autor- 
ka zde navozuje dojem jisté nespoutanosti, jíž dosahuje „[...] rychlým kladením vrstev rouna na barevně kontrastující podklad dobře [korespondující] s impulsivním charakterem technologie Art Protis“ (BŘEZINOVÁ 2018b: 58).

Další výrazný inspirační zdroj představuje hudba, respektive poslech hudby a vnímání melodie, jež se Tuschnerová snažila zachytit. Vystavená díla tematizují nejen onen zážitek; navíc se v některých $\mathrm{z}$ nich setkáváme se snahou textilními prostředky interpretovat i samotnou hudební partituru. Jedná se o takřka intimní spojení hudby a textilie, Art Protisu, vzniklé ve spolupráci s brněnským hudebním skladatelem Pavlem Blatným. Jako hlavní hudební inspirační zdroj výtvarnice jsou dále uváděny skladby Leoše Janáčka: „Výtvarné transpozice Janáčkových hudebních předloh - Řikadla, Po zarostlém chodnicku, Listy dưvěrné, Zápisnik zmizelého, Lašské tance vystihují podstatu hudební skladby, aniž by byly popisné“ (B̌̌EZINOVÁ 2018b: 58; NOVÁKOVÁ 1979).

\section{Textil a architektura}

Zatímco výše uvedené formy výtvarného projevu Inez Tuschnerové prezentovala výstava víceméně tradičně, prostřednictvím v prostoru umístěných dochovaných realizací, přípravných skic a studií, vznikl pro demonstraci využití netkané tapiserie coby

8 "Grafická notace některých avantgardních hudebních skladatelů, např́klad Anathetise Logothetise, inspirovala Pavla Blatného k tomu, aby na svých zahraničních kurzech prezentoval Art Protisy [Inez Tuschnerové] inspirované hudbou jako samotné partitury. Nápad myšlený původně spíše jako vtip se ukázal jako velmi zajímavý. Její kaligrafická textilní gesta řada studentů zcela samozrejmě považovala za vizuální partituru." (BŘEZINOVÁ 2018b: 58) textilní tapety specifický environment prostředí disponující vlastnostmi nezbytnými pro pochopení prezentovaného média.

Jednalo se konkrétně o simulaci interiéru vinárny hotelu Slovan v Košicích, kde ve spolupráci s architektem Vladimírem Kovaříkem pokryla Tuschnerová celý interiér veřejného prostoru Art Protisem (BŘEZINOVÁ 2018b: 59). Dnes již neexistující projekt z let 1967-1972 je unikátní tím, že netkanou tapiserii použili nejen na všechny stěny interiéru, ale také na strop, podlahu a v prostoru rozmístěné sloupy. „Zážitek z posezení v takovém interiéru musel být velmi intenzivní - na sytě červeném podkladu stěn a pilíruo zachytila expresivním rukopisným gestem folklorní tanec stylizovaných figur na hraně abstrakce v černých, bílých a modrých tónech vlny, červený koberec pokryla černou kaligrafií.“ (BŘEZINOVÁ 2018b: 59)

Prakticky totožně vypadala i jedna z místností přízemí Pražákova paláce, do které návštěvník vstupoval zatočeným, elipsově upraveným portálem vytvářejícím přechodovou izolaci od okolních síní (Obr. 4). Po vstupu se dotyčný ocitl doslova uvnitř textilního díla, výše zmíněného environmentu, jehož šarlatový interiér doplňovaly rozvěšené skici stylizovaných figur folklorních tanečnic, návrhy dílčích motivů výzdoby stěn a na podstavci umístěný prostorový model vinárny (Obr. 5). $\mathrm{V}$ instalaci umístěná naddimenzovaná dobová fotografie zachycující původní interiér zobrazovala taktéž původní sedací nábytek, který díky výraznému červenému potahu dotvářel celkový charakter pojednávaného prostředí.

Jednalo se tedy o různá zachycení prostoru, v jehož variaci se návštěvník sám nacházel. Jádro instalace spočívalo v samotném vnímaní prostoru; zakládalo 


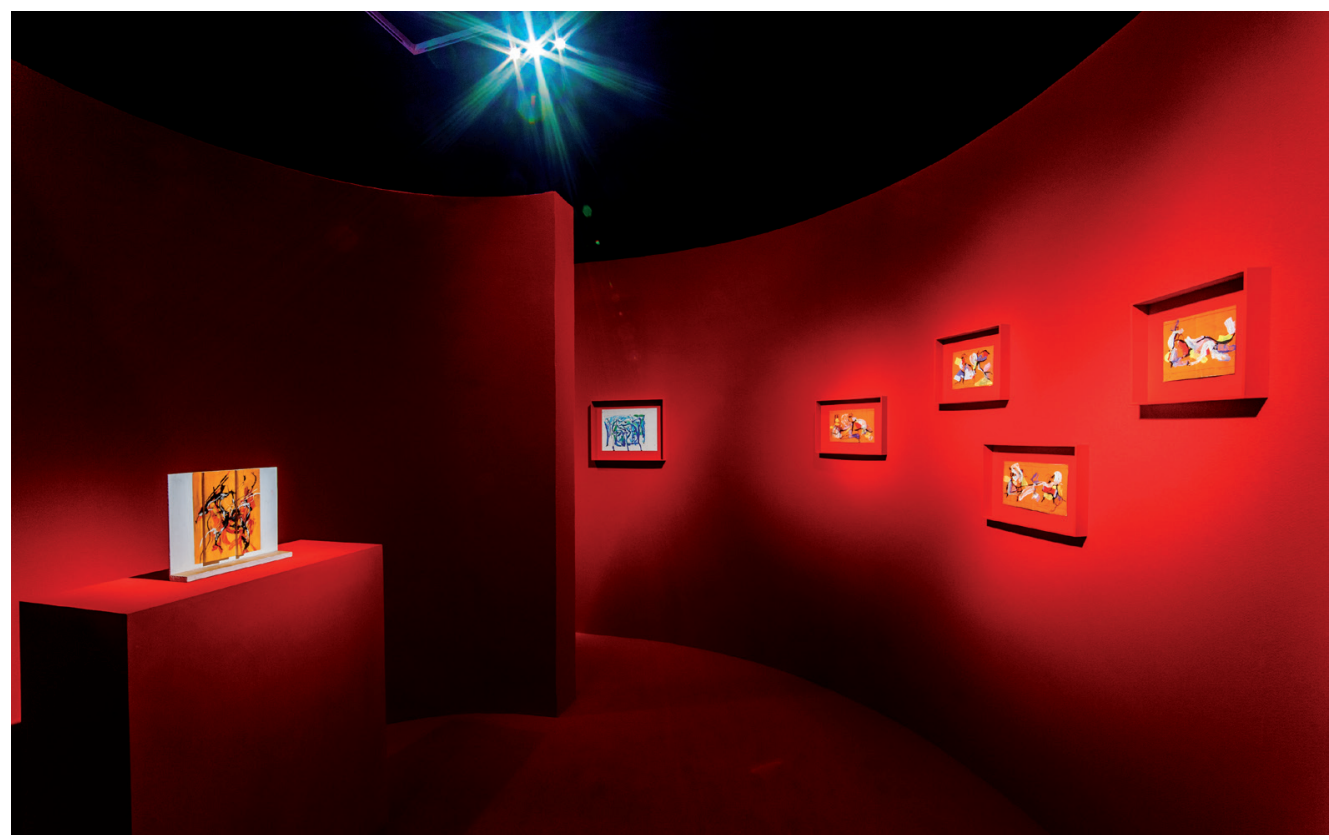

Obr. 4: Foto: Kamil Till (archiv MG)

se na radikálním použití textilie a akcentovalo její haptické a akustické působení. Za doprovodu tlumené reprodukované hudby, díky rafinovanému osvětlení a spirálovitému tvaru expozice se návštěvník setkal se vskutku originální výstavní formou na bázi scénografického řešení, jež intenzivně zpř́ítomňovala zmíněný interiér se všemi jeho (emocionálními) vlastnostmi.

Z dochované černobílé fotografie je dále patrné, že výjimečná byla i výstavní tvorba Tuschnerové, konkrétně její spolupráce s architektem Zdeňkem Langem na výstavním konceptu - instalaci výstavy liberecké společnosti Skloexport pro výstavu československého skla v Itálii (Obr. 6). Andrea Březinová v katalogu k výstavě upřesňuje, že se jednalo o výstavu Cristallo d'Arte Cecoslovacco pořádanou v roce 1977 v Římě, kde československá instala- ce „[...] oslnila nejen výběrem výstavního prostoru - architekt Lang jako první v novodobé historii využil historický objekt Traianovy tržnice -, ale také díky obřímu podstavci pro skleněné artefakty pokryté mnohavrstevnatým Art Protisem Inez Tuschnerové. Netkaná tapiserie s dynamickou abstraktní kompozicí a skleněné objekty vytvořily vizuálně působivý celek“ (BŘEZINOVÁ 2018b: 59).

\section{Punk a Střelnice}

V rámci expozice se mohl návštěvník setkat i s dalšími specifickými instalacemi, jež zhmotňovaly konkrétní dobové události. Jednalo se zaprvé o výstavu Inez Tuschnerové konanou v Bratislavě v roce 1986, jejíž simulace na návštěvníka čekala v místnosti pokryté černým igelitem s porůznu roz- 


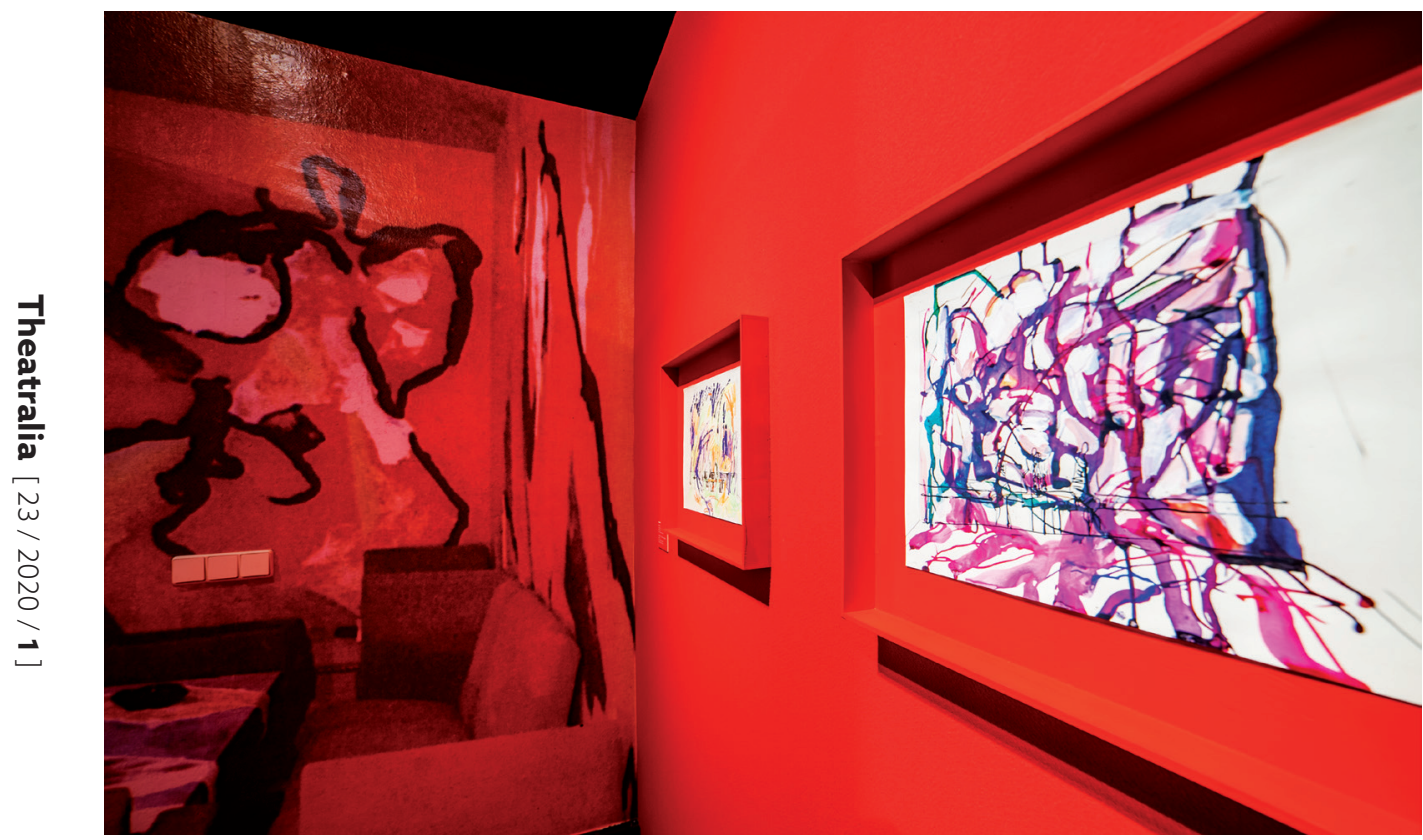

Obr. 5: Foto: Kamil Till (archiv MG)

místěnými dřevěnými paletami a prkny. Jak se dozvídáme z výstavních popisků, vyvolala zpř́itomňovaná výstava z roku 1986 skandál a po jediném dni byla ukončena. Důvodem bylo pravděpodobně ono surové pojetí expozice, Andreou Březinovou označené za „Punkové“, jež definovala černá barva a neopracovaná dřevěná prkna: „podlaha potažená černým igelitem, výtvarná díla na hrubých prknech opřených o zed', všemu dominující černá signatura autorky se stékající barvou“ (BŘEZINOVÁ 2018b: 59).

V kontextu „re-enactmenu“ této výstavy je potřeba opět upozornit na specifičnost doby a společensko-politické situace, jež tvorbu Tuschnerové ovlivňovala. Její tematicky a ideově neutrální díla, jako například Art Protisy s přírodními nebo hudebními motivy, byla sice bez problémů schvalována $\mathrm{k}$ realizaci a díla do interiérů národních podniků dokonce vysílána na zahraniční výstavy, přesto svou radikální výstavou zaměřenou výhradně na černobílá a monochromní díla vyvolala skandál: „[...] ,Punkové، pojetí prezentace přimělo úředníky výstavu po jediném dni zavřít" (BŘEZINOVÁ 2018b: 59).

Jiná z výstavních místností v Pražákově paláci tematizovala účast Tuschnerové na nejprestižnější přehlídce světové textilní tvorby, konané v letech 1962-1995, kterou bylo Mezinárodni bienále tapiserie $\mathrm{v}$ Lausanne. Jak se můžeme dočíst v katalogu k výstavě, dokazuje zmíněné bienále mj. tu skutečnost, že se „tradiční tapiserie během několika ročníků proměnila $\mathrm{v}$ prostorové dílo překračující hranici volného umění“ (BŘEZINOVÁ 2018b: 66). Uvedený posun zhmotňuje i textilní plastika Střelnice, jejíž fotografii poslala Tuschnerová na páté bienále, které se konalo v roce 1971. 






Obr. 6: Foto: archiv MG (katalog str. 56) 




Obr. 7: Foto: Kamil Till (archiv MG) 
komise vybrala zmíněný objekt k prezentaci v prostoru Palais de Rumine, kde měli diváci podle dobových výpovědí hned pochopit podtext díla, jímž autorka reagovala na srpnovou okupaci z roku 1968 (BŘEZINOVÁ 2018b: 66).

Střelnice je charakterizována jako textilní objekt s volně zavěšenými a pohyblivými figurami, který byl doprovázen dnes již neexistující hudbou Pavla Blatného (ten pro dané dílo zkomponoval dokonce dvě různě dlouhé verze hudebního doprovodu). ${ }^{9}$ Návštěvník dobové i pojednávané výstavy byl konfrontován s mohutnou skulpturou (finální realizace měřila tři a půl metru na výšku a přes dva metry na šířku), skládající se ze dvou dřevěných rámů: s napnutou černou textilií tvořící strunovité pozadí, a s tapiserií v přední rámu (Obr. 7). Jednalo se konkrétně o „bohatě strukturované černo-okrové pruhy tkané tapiserie prokládané přízí propletenou s vlněnými česanci v černé a sytě modré barvě. Do kompozice ,stromu' zavěsila [Tuschnerová] tři stylizované lidské figury se střeleckým terčem, ušité z výrazně oranžového Art Protisu s černým a okrovým rounem“ (BŘEZINOVÁ 2018b: 66).

\section{Divadlo}

Návštěvník výstavy se mohl ocitnout i v místnosti zcela věnované kostýmní tvorbě Tuschnerové, realizované jak pro divadlo, tak televizi. Vystaveny zde byly především návrhy kostýmních řešení, v menší míře i dobové fotografie $\mathrm{z}$ uváděných inscenací. Množství prezentovaných děl svědčilo o tom, že se Inez Tuschnero-

9 Nahrané pásky poslal do Lausanne ze svého turné ve Stuttgartu (BŘEZINOVÁ 2018b: 67). vá stala během několika let od ukončení studií vyhledávanou kostýmní návrhářkou významných českých scén. Návštěvník si mohl prohlédnout kostýmní návrhy například pro: Krajské oblastní divadlo v Brně - dnes Městské divadlo, Armádní umělecké divadlo Praha - dnes Divadlo na Vinohradech, Státní divadlo v Brně - dnes Národní divadlo Brno atd. (JOCHMANOVÁ a ZAHRÁDKA 2018: 113).

Z výstavní instalace taktéž vyplývalo - stejně jako ze samotné skutečnosti, že výtvarnice pro divadlo tvořila více než padesát let - že tvorba Tuschnerové prošla stylovou i formální proměnou v přístupu ke kostýmním návrhům. Té si v příslušné kapitole výstavního katalogu všímají Andrea Jochmanová s Jiřím Zahrádkou, kteří první návrhy z padesátých let charakterizují jako detailní a velmi formální: „Některé jsou zpracovány velmi realisticky, doslova popisně, jiné vychází z určité nadsázky a ironie a jsou do jisté míry stylizované. Autorka je kreslila černou linkou, kolorovala akvarelem, stínovala a pečlivě vypracovala drapérie. V návrzích jsou také detailně propracovány obličeje, které celkově naznačují, že mladá výtvarnice usilovala o prezentaci své kreslířské a malířské zručnosti spíše než o vnoření se do podstaty divadelních charakterů a samotného dramatu“ (JOCHMANOVÁ a ZAHRÁDKA 2018: 114).

U pozdějších děl můžeme naopak zaznamenat posun k významové zkratce, kdy jsou postavy vyvedeny jakoby $\mathrm{v}$ pohybu, pravděpodobně rychlým kresliřským tahem (Obr. 8). V těch případech jsou obličeje postav spíśe naznačeny, než detailně vypracovány. „Není to již deskriptivně vypracovaná kresba ohraničená zřetelnou konturou a čitelnými liniemi, ale jakási podstata oděvu podtrhující charakter jevištní postavy a její duševní rozpoložení, vždy důsledně v rámci 


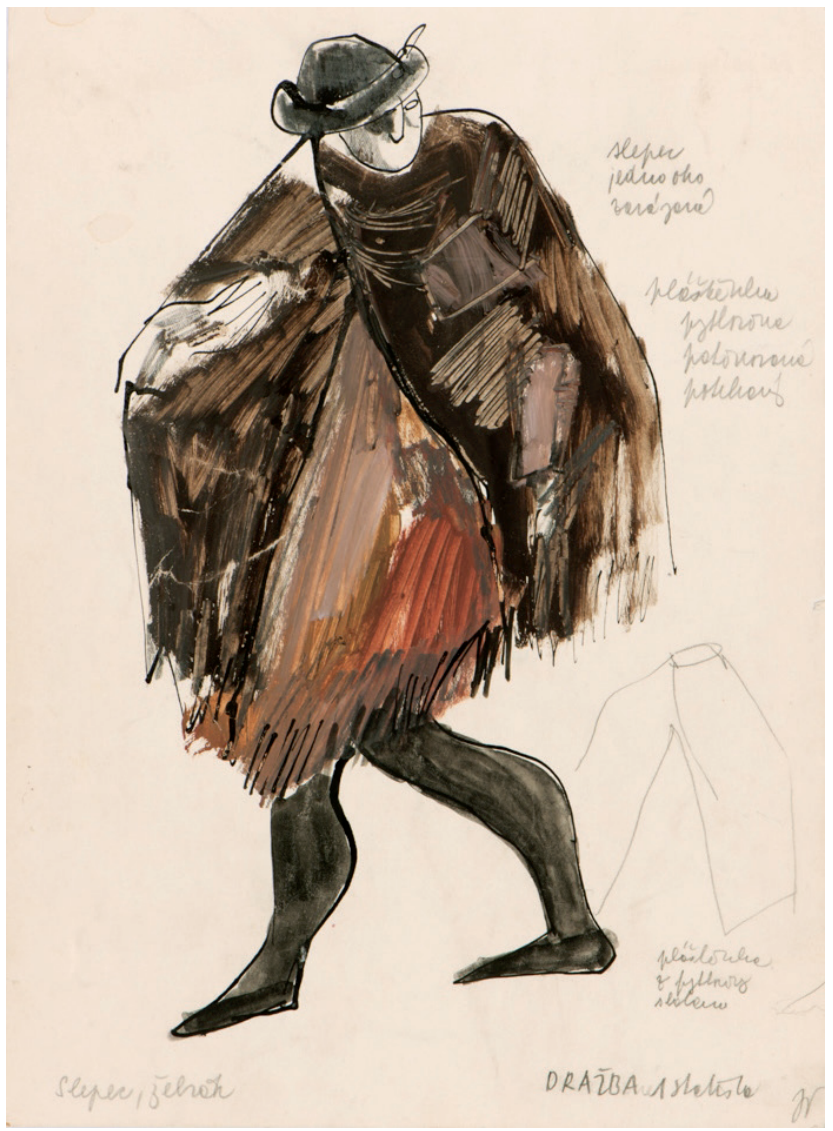

Obr. 8: Foto: archiv MG (katalog str. 108)

dané inscenační koncepce." (JOCHMANOVÁ a ZAHRÁDKA 2018: 114) Tuschnerová ve svých kostýmních návrzích taktéž zdůrazňuje materiálnost látky, jež textilní objekty definuje. A to např́klad vícevrstvým nanesením barvy, ,jindy užívala různých druhů špachtlí, v případě některých návrhů využívala i techniku koláže či asambláže“ (JOCHMANOVÁ a ZAHRÁDKA 2018: 114).

Pro realizaci svých kostýmních návrhů využívala Tuschnerová i nejmodernější textilie, jako výše zmiňovaný Art Protis specifický způsob výtvarného zpracování vlny. Jochmanová se Zahrádkou uvádí, že první návrhy s užitím netkané vlny vytvoři- la již v roce 1967, kdy šlo o více než šedesát kostýmů technologií protis, art protis a uni protis pro operní dílo Rienzi skladatele Richarda Wagnera. ${ }^{10}$ Nakonec ale k využití série kostýmů nedošlo a techniku Art Protis pro kostýmní realizace Tuschnerová poprvé využila až v roce 1988 v inscenaci Život Eduarda Druhého Anglického v tehdejším Státním divadle Brno (režie Evžen

10 Kostýmy byly vytvářeny pro Národní divadlo v Bratislavě, podle Moravského zemského archivu se mělo jednat o výzkumný úkol 298/67/2 Aplikace technologie Uni Protis na divadelní kostýmy VZ 1967, více viz (JOCHMANOVÁ a ZAHRÁDKA 2018: 115; BŘEZINOVÁ 2018b: 47). 
Sokolovský) (JOCHMANOVÁ a ZAHRÁDKA 2018: 115).

Divadelní tvorba Inez Tuschnerové je rozsáhlá, za svůj život vytvořila kostýmní návrhy pro téměř sto inscenací zejména brněnských divadel. Andrea Jochmanová s Jiřím Zahrádkou přitom vyzdvihují především režiséry Evžena Sokolovského, Miloše Hynšta a Aloise Hajdu coby její zásadní divadelní spolupracovníky (JOCHMANOVÁ a ZAHRÁDKA 2018: 115).

\section{Česká Helen Frankenthalerová?}

Tak zní jeden z podtitulů kapitoly věnující se analýze a interpretaci abstraktních prací Inez Tuschnerové, již pro katalog připravil kurátor Moravské galerie Petr Ingerle. Cílem pojednání je poukázat na podobnost výtvarného postupu objevujícího se v její tvorbě od konce šedesátých let, připomínajícího tzv. „,olor field paiting“, ,za [jehož] zakladatelku je považována americká představitelka tzv. druhé generace abstraktního expresionismu Helen Frankenthalerová (1928-2011). Americkou autorku, jejímž hlavním vzorem byl Jackson Pollock, spojuje s Inez Tuschenrovou, kromě užívání fluidních, tekutých tvarů linií, rovněž důraz na spontaneitu lyrického malîrského gesta, tvorba elementárních abstraktních kompozic, ale také práce pro divadlo, realizace $\mathrm{v}$ architektuře nebo pedagogické působení“ (INGERLE 2018: 97).

Díla založená na rozpíjení se barevných ploch či černých tušových linií do ručního papíru (nebo jiné podložky), tj. prríklady autorčiny volné tvorby, mohl návštěvník zhlédnout $\mathrm{v}$ instalacích gestických kreseb a různých prrípravných skic. Založeny jsou často na náhodném seskupení barvy, tj. na rozpití či skvrně a barevných cákancích, záro- veň jsou však pečlivě komponovány v rámci zvoleného formátu, vysvětluje Petr Ingerle. „Z hlediska abstrahování konkrétních motivů a forem dospívá Inez Tuschnerová ke stále oproštěněǰšímu gestu, pracuje s vědomým odkazem na čínskou a japonskou kaligrafii.“" (INGERLE 2018: 96)

Výstava prezentovala i tapiserie z cyklu Kompozice, které jsou založeny na výrazném a ve stručnosti vystihnutém záznamu gesta v kontrastu dvou barev. „Postupně [Tuschnerová] začala pracovat hlavně s kontrastem černé a bílé nebo rovnou s monochronní barevností. Tyto Art Protisy, plné dynamiky a napětí, tvoří reliéfní struktura pletenců vystupujících z plochy do prostoru." (BŘEZINOVÁ 2018b: 59)

Dynamika, napětí, abstrakce, expresivní gesto i soustředěná práce - charakteristické principy tvorby Inez Tuschnerové mohl návštěvník zachytit nejen na vystavených artefaktech, ale také v promítaném filmu Jana Špáty Hledáni nové krásy z roku 1972. Promítán byl na rozměrné plátno umístěné v rohové části vstupního atria Pražákova paláce, kde se tak porůznu objevovaly scény zachytávající Tuschnerovou přímo při práci, tj. klečíí - skloněnou nad velkoformátovými kusy tapiserií (Obr. 9). Scény připomínající například snímky Jacksona Pollocka při práci tzv. art - dripping na velkých plátnech se objevily i na jiných místech výstavy, stejně jako v doprovodném katalogu.

Kromě výše uvedených historiků a teoretiků umění se interpretaci díla Inez Tuschnerové věnoval také Jiř́ Valoch, který poukazuje na „skripturální gesto“ coby podstatu její práce i v kontextu média Art Protis: „Právě proto, že celá její tvorba byla ve znamení skladby díla $\mathrm{z}$ většího, nebo menšího množství autorských gest, byla vlastně jakoby zrozena pro tuto novou technologii, spočívající ve volném, dynamickém kladení 




Obr. 5: Foto: archiv MG

česanců vlákna na podklad a potom prošívaným“ (VALOCH 2018 [2007]: 91).

\section{Bibliografie}

BŘEZINOVÁ, Andrea. 2018a. Inez Tuschnerová. Úvod. In Inez Tuschnerová, Andrea Březinová a Jiří Zahrádka (eds.). Inez Tuschnerová. Brno: Moravská galerie, 2018: 3-24.

BŘEZINOVÁ, Andrea. 2018b. Textilní tvorba. In Inez Tuschnerová, Andrea Březinová a Jiří Zahrádka (eds.). Inez Tuschnerová. Brno: Moravská galerie, 2018: 25-75.

INGERLE, Petr. 2018. Co se skrývá za abstrakcí v pracích Inez Tuschnerové? In Inez
Tuschnerová, Andrea Březinová a Jiří Zahrádka (eds.). Inez Tuschnerová. Brno: Moravská galerie, 2018: 83-112.

JOCHMANOVÁ, Andrea a Jiří ZAHRÁDKA. 2018. Kostýmní návrhy. In Inez Tuschnerová, Andrea Březinová a Jiří Zahrádka (eds.). Inez Tuschnerová. Brno: Moravská galerie, 2018: 113-144.

NOVÁKOVÁ, Milada. 1979. Inez Tuschnerová. Katalog k výstavě v Domě umění. Brno, 1979.

PTÁČKOVÁ, Věra a Jan DVOŘÁK (eds.). 2008. Divadlo na konci suéta: stati o scénografii. Praha: Pražská scéna, 2008.

TUSCHNEROVÁ, Inez, Andrea BŘEZINOVÁ a Jiř́i ZAHRÁDKA (eds.). 2018. Inez Tuschnerová. Brno: Moravská galerie, 2018. 
